\title{
KISEGÍTŐ BERENDEZÉS ERGONÓMIAI SZEMPONTJAI
}

\author{
Kántor Kristóf \\ BSc Géptervezö hallgató, Miskolci Egyetem, Gép-és Terméktervezési Intézet \\ 3515 Miskolc, Miskolc-Egyetemváros, e-mail: kant.kristof@gmail.com \\ Benyó Klára \\ mesteroktató, Miskolci Egyetem, Gép-és Terméktervezési Intézet \\ 3515 Miskolc, Miskolc-Egyetemváros, e-mail: machbk@uni-miskolc.hu \\ Bihari János \\ egyetemi docens, Miskolci Egyetem, Gép- és Terméktervezési Intézet \\ 3515 Miskolc, Miskolc-Egyetemváros, e-mail: machbj@uni-miskolc.hu
}

\begin{abstract}
Absztrakt
A berendezés alkalmazási területe miatt szükséges ergonómiai vizsgálat lépéseit mutatjuk be. A téma multidiszciplináris volta miatt az alapvetö ergonómiai szempontokon túlmenöen, a biomechanika és az autóipari szabványok, ajánlások területét is érintve a tervezéshez használható elveket, útmutatásokat készitünk.
\end{abstract}

Kulcsszavak: ergonómia, rehabilitációs mérnöki munka, jármü átalakitás, kormányszerkezet

\section{Abstract}

We present the process of the human factor analysis, required owing of the application of the device. Beyond the basic human factors we use the biomechanic, standards and principles of the automotive industry owing of the multidisciplinary being of the theme to make instructions for designing.

Keywords: human factor, rehabilitation engineering, vechicle modification, steering device

\section{Bevezetés}

Mindennapi használati tárgyaink tervezése során az emberközpontú tervezés viszonylag új keletü megközelítés. Fontosságára a második világháborút követően figyeltek fel. A hadiiparnak, és a hidegháború időszakában oly sok fejlődést magával hozó üriparnak köszönhetően rohamos fejlődésbe kezdett az ergonómia. A század végére nagy területet lefedő tudománnyá forrta ki magát, ennek köszönhetően a hétköznapi szókincs részévé vált a fogalom.

A gyógyászati eszközök tervezése során különösen fontos a berendezések optimális kialakítása. Sérült emberek számára tervezett eszközöknél az ember-gép rendszert célszerü úgy kialakítani, hogy a felhasználónak egyáltalán ne, vagy csak kis mértékben kelljen alkalmazkodni az eszközhöz.

\section{A berendezés}

A vizsgált berendezés, melyet az 1. ábra mutat, autókba utólagosan beépíthető termék, amely segítségével azok az emberek is önállóan vezethetik a jármüvet, akiknek valamelyik, vagy minden felső végtagja bénult. A karok mozgása a bal láb segítségével helyettesíthető, mellyel egy tárcsát (1.) forgatnak, így az alsó végtag lineáris mozgását forgó mozgássá alakítva rugalmas hajtásokon (2.) keresztül mü- 
ködtetni tudják a jármü eredeti kormányszerkezetét (3.). A hajtás kinematikai láncában található egy előtéttengely (4.), amely azért szükséges, hogy a mai autók nem egyenes középvonalú kormányoszlopaival is kompatibilis legyen a berendezés. [1]

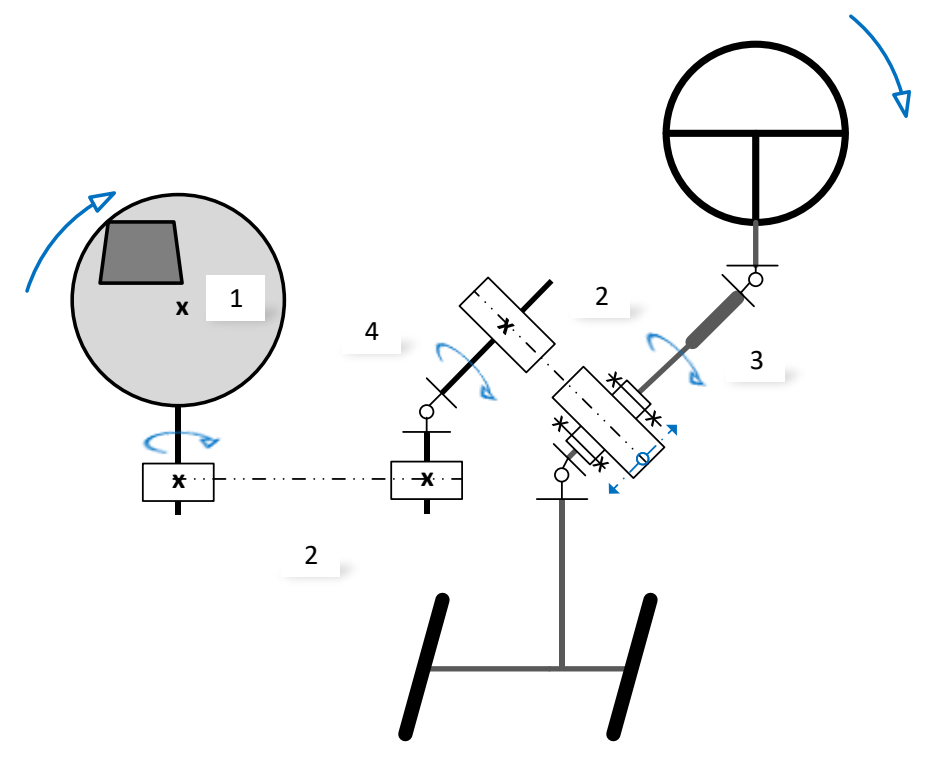

1. ábra. A vizsgált berendezés

\section{Ergonómiai szempontok}

Az ergonómiai szempontokat két csoportra lehet felosztani. Az egyik csoport fizikai jellegủ szempontokat tartalmaz, míg a másik geometriai jellegüeket.

\subsection{Fizikai jellegü szempontok}

A fizikai jellegü szempontok közé erők és nyomatékok tartoznak. A munka ehhez tartozó részében az a feladatunk, hogy megtaláljuk az autóipari elöírások és az alsóvégtag erőkifejtése közötti egyenlöséget.

Az autóiparra vonatkozó előírások szabályozzák a kormánykerék elfordításához szükséges maximális erő nagyságát, valamint a kormánykerék átmérőjét is. A müködtetéshez szükséges erőt mind rásegítéses, mind rásegítés nélküli kormányszerkezet esetén korlátozzák az előírások [2]. Ebből a két adatból számolható az a forgatásinyomaték-határérték, amelyet a tervezett szerkezettel szintén be kell tartani.

Az emberi erőkifejtés alapvetően a nem és az életkor függvénye. A vizsgálat során a sport hatását szándékosan figyelmen kívül hagytuk. A nők a férfiak erejének megközelítőleg $65 \div 70 \%$-át képesek kifejteni. Mindkét nem 25 és 30 év között képes a legnagyobb erőkifejtésre, utána minden évtized elteltével nagyjából $5 \div 10 \%$-kal csökken az erökifejtés maximális értéke. [3]

Az alsó végtag esetében az előző tényezőkön kívül a térd hajlítási szöge is befolyásolja a kifejthető erőt [4]. A térd nyomatéka vizsgálatokkal mérhető, melyből biomechanikai modell segítségével számítható a mozgás kerületi ereje. (2. ábra) Ez az az erő, amellyel a tárcsát a soför mozgatni tudja. A térd vizsgálatának eredménye egy diagram, amely a nyomaték és a hajlítási szög kapcsolatát mutatja. 


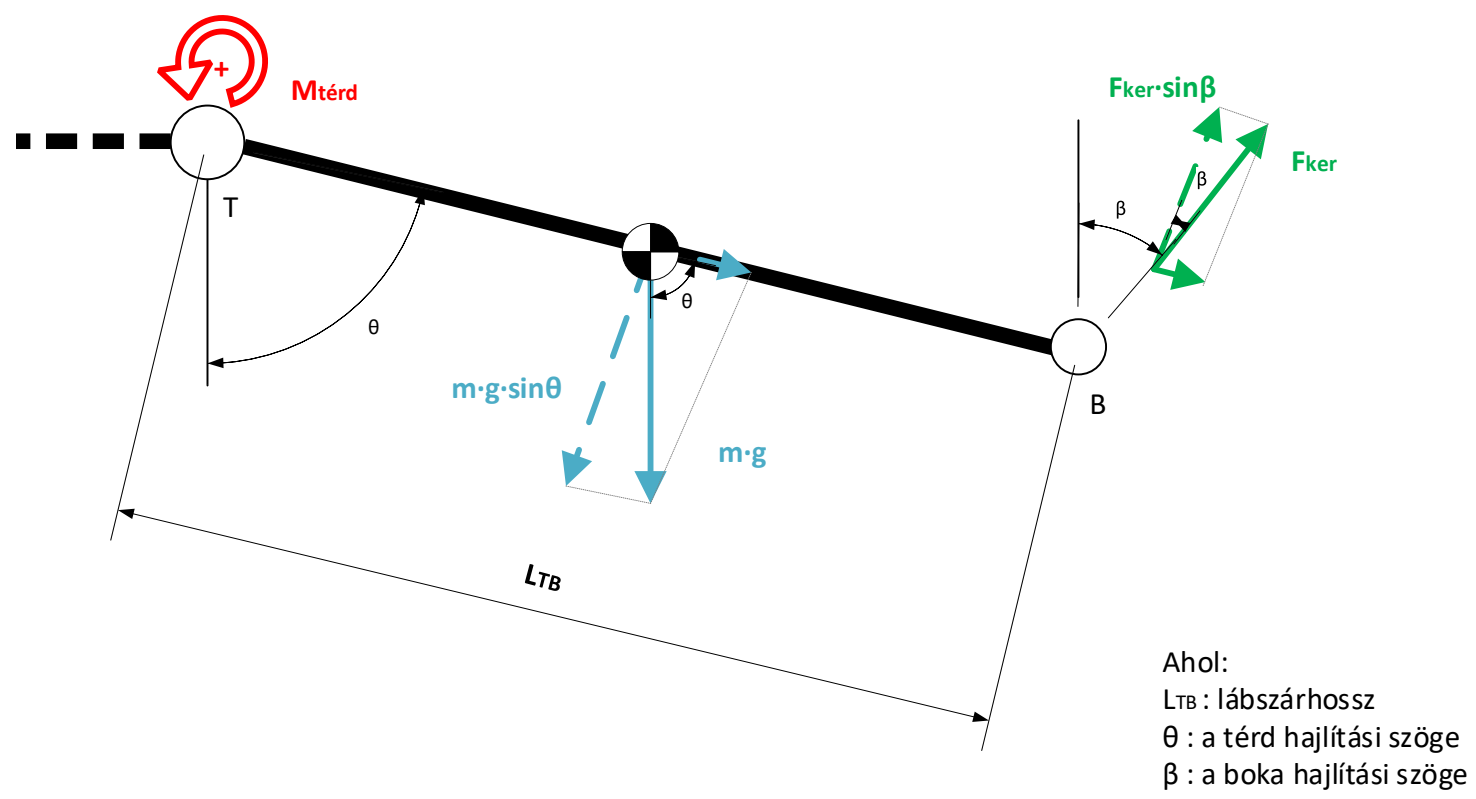

2. ábra. A használt biomechanikai modell

A 2. ábra alapján felírható az alábbi összefüggés, amellyel számítható a szükséges erő.

$$
\left|F_{k e r}\right|=\frac{1}{\sin \beta} \cdot\left(\frac{M_{\text {térd }}(\theta)}{L_{T B}}+\frac{m \cdot g \cdot \sin \theta}{2}\right)
$$

Az összefüggésben látható, hogy míg a hossz és tömegméretek egyénfüggőek és könnyen mérhetöek, addig a térd és a boka hajlítási szöge a beépítés helyzetétöl függ.

\subsection{Geometriai jellegü szempontok}

A gépjárművek belterének kialakítását számos elöírás szabályozza. A méretek és erők meghatározásának szempontjából fontos elöírás az ülö ember combcsont-fejének pontja [3]. Ekörül mozog a comb, és ez határozza meg a legfőbb méreteket és pontokat, melyek a gázpedált kezelő jobb lábra vonatkoznak, azonban alkalmazhatóak a bal lábra is. A meghatározott méretek között van a gázpedál müködtetésekor a boka hajlítási szöge, valamint a csípő és a talp-pedál érintkezési pontja is.

A gázpedál és a fékpedál geometriájának ismeretében behatárolható a tárcsa helye a lábtérben. Fontos, hogy a tárcsa forgatás közben ne akadjon bele a padlólemezbe, így a 3. ábra szerinti jelölés alapján t' hézagot kell hagyni. Az elhelyezésnél szintén figyelembe, kell venni, hogy a fékpedálba sem akadhat bele a szerkezet. Az ábra megrajzolásához szükséges L53, azaz a csípő-sarokpont távolságának értéke az alábbi módon számítható.

$$
L 53=X_{95}-\left(L+L F+L T-L t^{\prime}\right)
$$

Az egyenletben szereplő tagok az alábbiak: $\mathrm{X}_{95^{-}}$a gázpedál-csípő távolság az amerikai sofőrök 95\%-ának megfelelően; az L tagok pedig sorban a következők: a gázpedál-, fékpedál-, lábtárcsa- és a lábtárcsa-hézag vízszintes vetülete. 


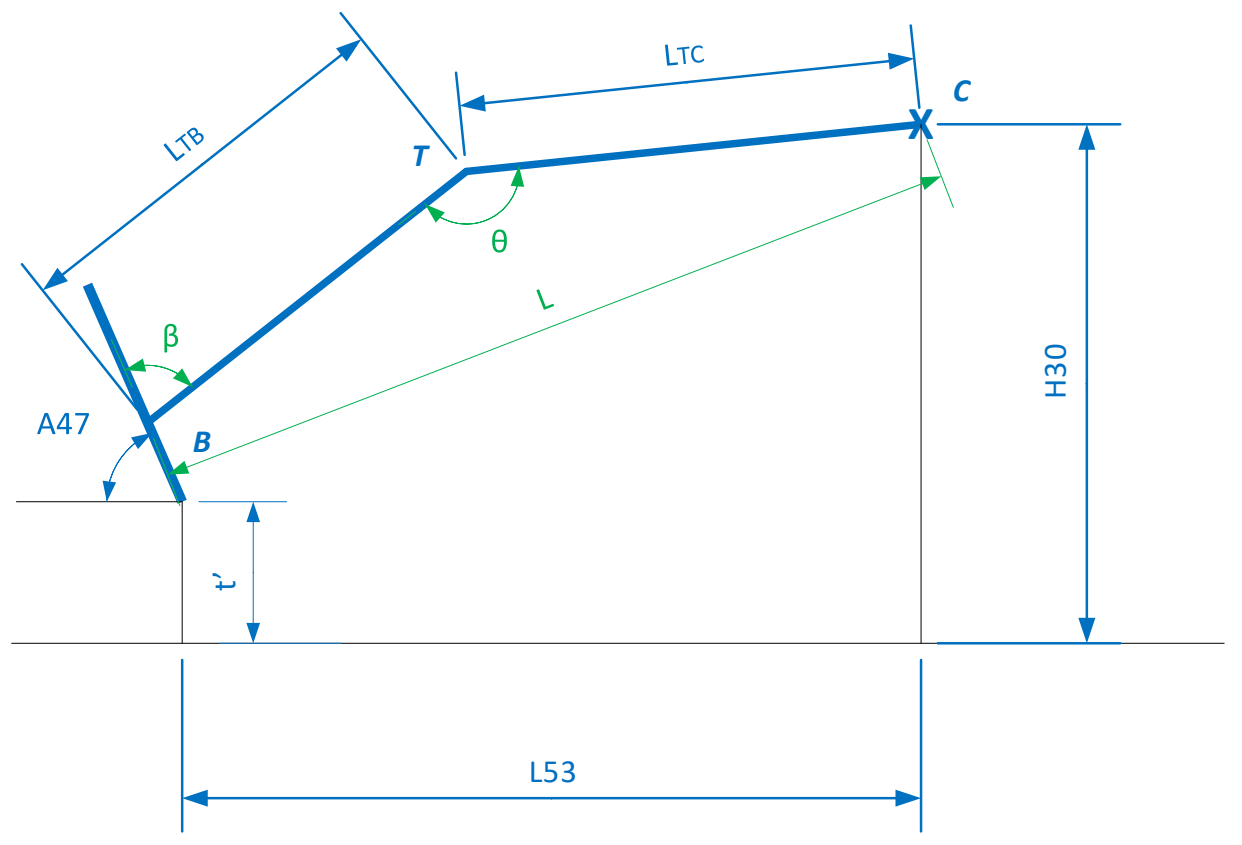

3. ábra. A tárcsa helyének meghatározása

Ha ismertek a fentiekben említett adatok, a tárcsa dőlésszöge és az alsó végtag méretének jellemző értéke, megszerkeszthető a 3. ábra. A lábszár hosszának, azaz az $\mathrm{L}_{\mathrm{TB}}$ értékének meghatározásakor befolyásoló tényező az öltözet hatása is. A hatás nagyságának megállapításához iránymutatások alkalmazhatóak. A szerkesztést követően a hajlítás szögei behelyettesíthetők az (1) számú egyenletbe. A kapott $\mathrm{F}_{\mathrm{ker}}$ kerületi erő segítségével pedig megállapítható a szükséges tárcsaátmérő.

\section{4. Összefoglalás}

Ahogy az a fentiekből látható, számos tudományterületet érintve lehet eljutni a végeredményhez. A bemutatott számítás a gyakorlatban nem mindig ebben a formában jelenik meg, mivel a bemutatott módszer egy jármü tervezésekor használt adatokból indul ki. Fontos, hogy minden esetben az adott jármü belsőterének kialakítását kell alapul venni, mivel ez típusonként eltérö lehet. Az összefüggésekben használt emberfüggő méretek és adatok általában pontosan mérhetők, azonban, ha ez nem lehetséges, antropometriai táblázatok használata szükséges.

\section{Köszönetnyilvánítás}

A cikkben ismertetett kutató munka az EFOP-3.6.1-16-2016-00011 jelü „Fiatalodó és Megújuló Egyetem - Innovatív Tudásváros - a Miskolci Egyetem intelligens szakosodást szolgáló intézményi fejlesztése" projekt részeként - a Széchenyi 2020 keretében - az Európai Unió támogatásával, az Európai Szociális Alap társfinanszírozásával valósul meg. 


\section{Irodalom}

[1] Bihari, J. Információs eszközök a gépjármüvekben, Géptervezők és Termékfejlesztők XX. országos Szemináriuma, 2004, 4.1 pont

[2] Kádár, L., Varga, F.; Kőfalusi, P. Közúti jármürendszerek szerkezettana. Elektronikus jegyzet. Készült: „Mechatronikai mérnök MSc tananyagfejlesztés” TÁMOP-4.1.2.A/1-11/1-2011-0042, http://www.mogi.bme.hu/TAMOP/kozuti_jarmurendszerek_szerkezettana/book.html

[3] Bhise, V.D. Ergonomics in the Automotive Design Process, CRC Press, Boca Raton, 2012

[4] Nordin; M., Frankel, V.H. Basic Biomechanics of the Musculoskeletal System, Lippincott Williams \& Wilkins, Philadelphia, 2012 